\title{
Groundwater Protection Using Vulnerability Maps and Wellhead Protection Area (WHPA): A Case Study in Mexico
}

\author{
Jose Luis Expósito • Maria Vicenta Esteller • \\ Jorge Paredes · Celso Rico · Roberto Franco
}

Received: 7 October 2009 / Accepted: 14 April 2010 /

Published online: 18 May 2010

(C) Springer Science+Business Media B.V. 2010

\begin{abstract}
The need to protect groundwater resources against quality deterioration due to anthropogenic activities is unquestionable. The concept of aquifer pollution vulnerability maps and of wellhead protection areas (WHPA) as protection tools is not new; however, in spite of the elapsed time, their use has been increased as a result of the increase in economic development-and everything that this entails-and the increase in prohibitive costs of treating contaminated water or of the decontamination of aquifers. The study's objective was to establish an integrated method that defines, first of all, the areas of highest vulnerability in the aquifer, and second, within these areas, the wells that most urgently need protection. To identify these wells, additional criteria were taken, such as well constructive data, pumped volume, and the region's socioeconomic characteristics (social exclusion index). Once the wells were ranked, several of them were chosen as a pilot study to compare different methods for the delineation of WHPA based on calculated fixed radius and analytical methods and, this way, identify which method or methods best adapt to the characteristics of the study area. The Minkin analytical method proved to offer the best results since it protects well on both sides and achieves a balance in the well's upgradient distances. It is also worth mentioning that the delimitation of the WHPAs in the study area was limited in respect to hydrogeologic and technical data.
\end{abstract}

Keywords Groundwater protection • Aquifer vulnerability • Wellhead protection area $($ WHPA $) \cdot$ Drinking water $\cdot$ Mexico

\footnotetext{
J. L. Expósito · M. V. Esteller $(\varangle)$ · J. Paredes · C. Rico

Centro Interamericano de Recursos del Agua (CIRA). Facultad de Ingeniería,

Universidad Autónoma del Estado de México, Cerro Coatepec S/N 50130 Toluca, México

e-mail: mvestellera@uaemex.mx

R. Franco

Facultad de Geografia, Universidad Autónoma del Estado de México,

Cerro Coatepec S/N 50130 Toluca, México
} 


\section{Introduction}

The experience in the last decades has shown that groundwater is not immune to contamination and that once it is contaminated by chemical, biological or radiological agents, it is nearly always hard to clean and the possibilities of remediation involve high economic costs (UN 2006; Wang 2006).

There is no doubt that the safest way to achieve absolute protection against groundwater contamination would be to stop all type of potentially contaminating activities. Nevertheless, this would be impossible to carry out due to the technical and, most of all, economic implications that this would involve (Wang 2006).

In this sense, in stead of applying universal controls over land use on a regional level and effluent discharge to the ground, it is more cost-effective (and less prejudicial to economic development) to define the level of control required on a more local scale (De Loë et al. 2002; Fadlelmawla and Dawoud 2006). Simple and robust zones, which can be defined based on aquifer pollution vulnerability and wellhead protection areas, must be established (Hirata and Reboucas 1999), indicating which anthropogenic activities are possible and where they can be located, at an acceptable risk to groundwater (Foster et al. 2002; Sylvestre and Rodriguez 2008).

Aquifer vulnerability is defined as "an intrinsic property of a groundwater system that depends on the sensitivity of that system to human and/or natural impacts" (Vrba and Zaporec 1994). There are several methods to determine this vulnerability, which have been modified in the last years to adapt to different hydrogeological environments (Hirata and Reboucas 1999; Gogu and Dessargues 2000; Massone et al. 2010). Most of these methods are based on index and overlaying techniques. The combination of maps with a spatial distribution of data with specific attributes (soil, geology, groundwater depth, etc) leads to the assignation of a numerical index or a value for each attribute. These are combined to produce a vulnerability score. This score is reflected in a map — the vulnerability map-which produces information regarding the ease with which the groundwater can be contaminated by an external agent. The obtained map is of great use, for example, for land use planning.

Common methods are DRASTIC (Aller et al. 1985), SINTACS (Civita 1994), AVI (Van Stempvoort et al. 1992) and GOD (Foster and Hirata 1988; Foster et al. 2002). There have been studies comparing these different methods (Gogu et al. 2003); as well as research attempting to conduct a validation of the vulnerability maps obtained through the use of numerical models, for example (Neukum et al. 2008).

A wellhead protection area (WHPA) is based on the establishment of a system of zones surrounding the well, inside of which activities that are liable to modify the groundwater quality are restricted or prohibited in a gradual manner (depending on their proximity to the well; US Environmental Protection Agency 1993).

The WHPAs, as a protection tool for groundwater, are still being enforced at present, as evidenced by a recent study in South Africa by Nel et al. (2009) and there is a search to define methods which, with minimal information, guarantee the obtaining of real WHPAs (Miller et al. 2003; Paradis et al. 2007; Exposito et al. 2007; Garfias et al. 2008), likewise, there is research into new concepts such as well vulnerability (Frind et al. 2006).

According to the US Environmental Protection Agency (1993), the main assessment methods for WHPAs can be reduced to six, which can be classified in an ascending order with regard to complexity and costs, into arbitrary fixed radius, 
calculated fixed radius, simplified variables shapes, analytical methods, hydrogeological mapping and numerical flow and transport models.

Choosing the appropriate method requires specific procedures that consider the amount of hydrogeological data that is necessary, the hydrogeological complexity, the required accuracy of the results, time, human resources, the capabilities of the groundwater management agency, and available funding (Miller et al. 2003; Fadlelmawla and Dawoud 2006).

The study's objective was to establish an integrated method that defines, first of all, the areas of highest vulnerability in the aquifer, and second, within these areas of highest vulnerability, the wells that most urgently need protection. Once these wells are identified, an evaluation is conducted of the different methods for the delineation of protection areas, which will allow defining the method that helps obtain a delineation of the areas that are to be protected, in a sufficiently precise, simple and low-cost manner, according to the existing conditions in the study region.

To apply these concepts, the aquifer of the Valley of Toluca, in central Mexico, was chosen as study area. There is intense exploitation of this aquifer, a growing demand for groundwater for different types of supply, constant increase in contamination risk and an intense and, in many cases, inordinate population growth (Esteller and Díaz-Delgado 2002; Esteller and Andreu 2005).

\section{Study Area}

The study area, the aquifer of the Valley of Toluca (Fig. 1) is located in the central area of Mexico, more specifically in the central zone of the State of Mexico, and is one of the highest in elevation in the Mexican Highlands. It borders the AtlacomulcoIxtlahuaca Aquifer to the north, the Tenango Hill to the south, the Nevado de Toluca Volcano to the south-west and Sierra de Las Cruces and Monte Alto to the east.

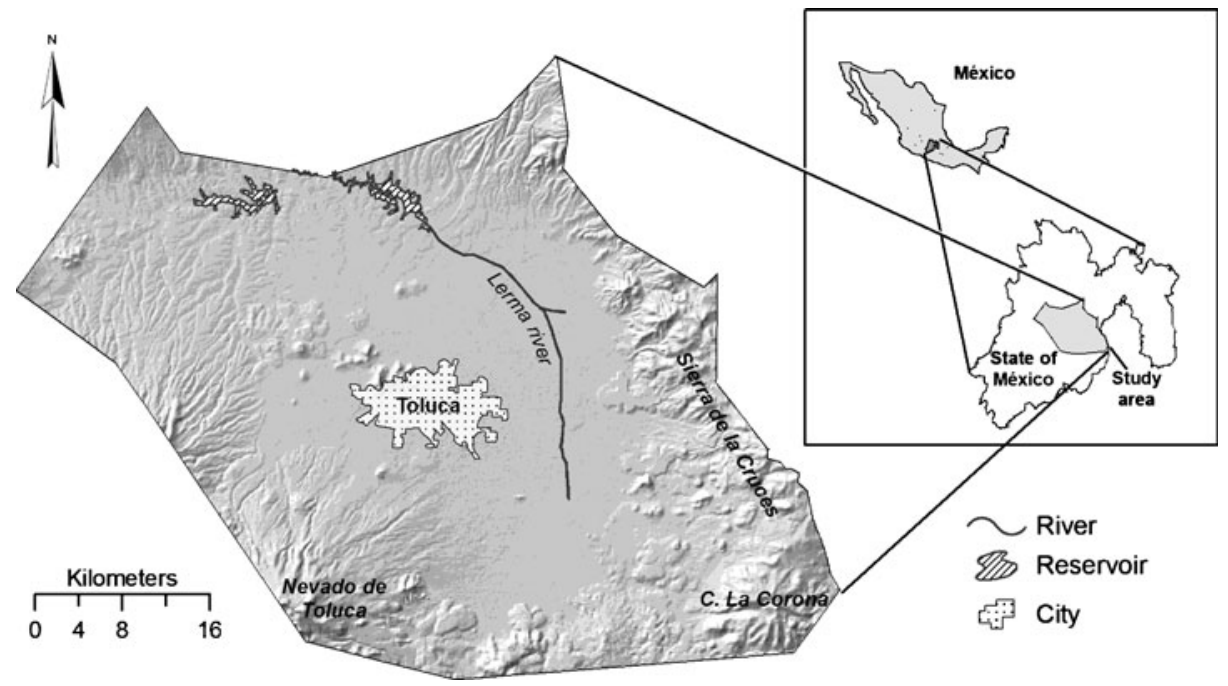

Fig. 1 Location map for the study area. Valle de Toluca (Mexico) 
The climate can be considered as humid temperate with abundant rainfall in the mountain areas $(1,000 \mathrm{~mm} /$ year $)$ and less rainfall in the valley $(700 \mathrm{~mm} / \mathrm{year})$, the rain season being from May to September. Temperatures vary considerably, with mean monthly temperatures ranging between $5^{\circ} \mathrm{C}$ (at altitudes of over 3,000 m.a.s.l.) and $25^{\circ} \mathrm{C}$ (in areas located in the valley).

The aquifer of the Valley of Toluca is formed by noticeably heterometric detrital material, predominated by gravel, sand, and conglomerates with clayey silt matrix, although it is also possible to distinguish pyroclastic intercalations with layers of tephra and tuff. Based on these characteristics, it can be pointed out that this system is formed by several superimposed aquifer layers that constitute a multilayered aquifer, but the existence of hydraulic continuity allows us to consider a single-flow system. Nevertheless, there are significant differences in the hydraulic head. This detrital material lies over a foundation comprised of consolidated volcanic matter of a variable nature, predominantly basalt and andesite (Unitecnia Company 1996). These basalts and andesites represent a continuation of the volcanic deposits that form the mountain ranges and make up the fractured aquifers whose main function is to recharge the Valley of Toluca aquifer.

The hydraulic parameters of the aquifer of the Valley of Toluca fluctuate over a wide range due to the lithologic and geometric variability of the deposits. Hydraulic conductivity values range between 0.4 and $80 \mathrm{~m} /$ day and effective porosity varies between $0.3 \%$ and $0.9 \%$ (CCRECRL 1993).

This valley is an important economic center in the country and has a high population density that has led to an increase in water demand which is being covered almost entirely by groundwater.

The total volume of water extracted is $425 \mathrm{Mm}^{3} /$ year, out of which $358 \mathrm{Mm}^{3} /$ year $(84 \%)$ are destined to public-urban use both in the valley and in Mexico City. The number of wells destined for this use amounts to 404, out of which 178 extract water for Mexico City. Agricultural use demands $7 \%$ of the extracted volume, and the same percentage goes to industrial use. The rest is used for services, cattle and aquaculture. Due to this intense exploitation, the aquifer is under prohibition and the construction of new wells is not allowed (CONAGUA 2002).

\section{Materials and Methods}

The development of this research was defined based on three stages: the first stage was focused on the elaboration of the pollution vulnerability map; in the second stage, a series of criteria was applied to prioritize wells located in the aquifer's most vulnerable zones; and the third stage consisted of employing and comparing different methods to define the protection areas.

\subsection{GOD-based Vulnerability Mapping}

There are several methods for the determination of aquifer vulnerability. These methods differ regarding the parameters that are used; there are methods that use a significant number of parameters, while others are based on only a few parameters (Martínez and García 2003). 
In this sense, the first step towards conducting the groundwater pollution vulnerability mapping was choosing the method that would be employed. According to Auge (2003), the choice of method depends on factors such as knowledge of the methodology, available information, and scope of the evaluation.

Once the previous criteria was analyzed, it was concluded that the GOD method (Foster et al. 2002) will be used, because this method is widely used in Latin-America, the necessary information for its application in the study area is available, and also, the extension of the work area demands the use of a working scale higher than $1: 100,000$.

Both the GOD method, as well as other commonly used methods (DRASTIC; SINTACS), only offer qualitative results; however, considering the scale of the works $(1: 250,000)$ and the uncertainty of the values of some parameters such as recharge, it was considered that the GOD method would offer an acceptable estimation of the area's level of vulnerability as a first approach to a more detailed study on vulnerability.

\subsection{Selection and Prioritization of Supply Wells}

The great number of wells that are destined for public-urban use in the study area (404 wells) raises the need for previous planning in order to establish which wells should have priority in regard to protection; therefore, once the pollution vulnerability map was obtained, wells were chosen that needed protection in a prioritized manner within the areas of greatest vulnerability, based on priority criteria defined by Martínez and García (2003) and adapted to the conditions of the study area.

The method used was the following:

- Based on the well inventory provided by National Water Commission (CONAGUA) - the government institution in charge of the management, care and preservation of water in Mexico, wells destined for public-urban use were selected.

- Wells that supply water to Mexico City were eliminated. Exclusion of this wells was exclusively because, given the geographic proximity among these wells, the interference produced by their joint exploitation would generate excessively complex protection perimeters that are hard to estimate using analytical methods (Hirata and Reboucas 1999). These wells display, without a doubt, high protection priority, and so the delineation of a common protection area could be conducted through numerical modeling in later stages of the research.

- The rest of the exploitation wells of the database were placed in the vulnerability map, identifying those that are located in the areas of highest vulnerability.

- Populations located near wells were sited and classified according to index of social exclusion. The index of social exclusion includes a set of variables related to the population, its economic conditions and housing characteristics, and quality of life. This index is assessed for all the country's municipalities by the National Population Council (CONAPO 2001). The use of the social exclusion index in the prioritization of wells was considered as a way of evaluating the potential contaminant load that can reach the aquifer due to deficiencies in the management of solid and liquid wastes. These wastes might not represent large values, but they must be considered as sources of contamination. 
In addition, this index is also useful in the evaluation of material and human resources that are available for maintaining the well in proper exploitation conditions, for locating alternative sources of water supply in the case of contamination events, or even to have proper medical attention in the face of waterborne diseases (the greater the social exclusion index, the less the availability of human and material resources; Montgomery and Elimelech 2007).

- The possible influence of land use was analyzed at the time of choosing the wells that were to be protected, using the land use map elaborated by National Institute of Statistics, Geography and Data Processing (INEGI 2003). For example, wells located in areas used for agriculture have a higher priority of protection, because these farming areas receive contaminant loads from the use of agrochemicals. By contrast, wells located in areas where land use is for forest or pasture, are not a priority because there are no pollutant loads.

- An analysis was conducted for each well, including the year in which it was constructed and the extraction volume, information obtained from the National Water Commission (CONAGUA, its Spanish acronym) inventory.

The age of the well was related to the identification of wells that have exceeded their service life (20 years) and are still operating. Higher priority was assigned to these wells, given the possibilities of structural failures that could facilitate the entry of pollutants.

The exploitation volume was considered as being more relevant than the age of the well, since the volume (considering that these wells are exclusively for urban use) reflects the number of people who could be affected by a potential contamination event (the greater the volume, the greater the population that is being supplied).

\subsection{WHPA Methods Application and Comparison}

The delineation of a protection area around one or several wells is the most important stage in the implementation of the WHPA program (US Environmental Protection Agency 1993). Nevertheless, in order to proceed with the selection of the method or methods to be used, it is necessary to determine if the required information is available and whether it has the required reliability (Paradis et al. 2007).

In the analyzed case, once the geological and hydrogeological works that have been conducted in the study area were revised, it was concluded that there is lack of data necessary for the application of methods based on numerical models; however, some parameters were determined so as to delineate the protection areas through other methods based on fixed radius and those of analytical nature.

Based on the available information (pumped volume, hydraulic gradient of the area, hydraulic conductivity and effective porosity of the geological materials where the aquifer is developed), it was concluded that the application of the following methods is feasible: calculated fixed radius in its volume version, and the analytical method in the versions of Wyssling (Moreno and Martínez 1991), Minkin (Oradoskaia and Lapchin 1987) and Perez and Menendez (Perez et al. 1998).

All these methods agree on dividing the WHPA into different zones around the well, graded from most significant to less significant in relation to the restrictions of 
Fig. 2 The WHPA concept

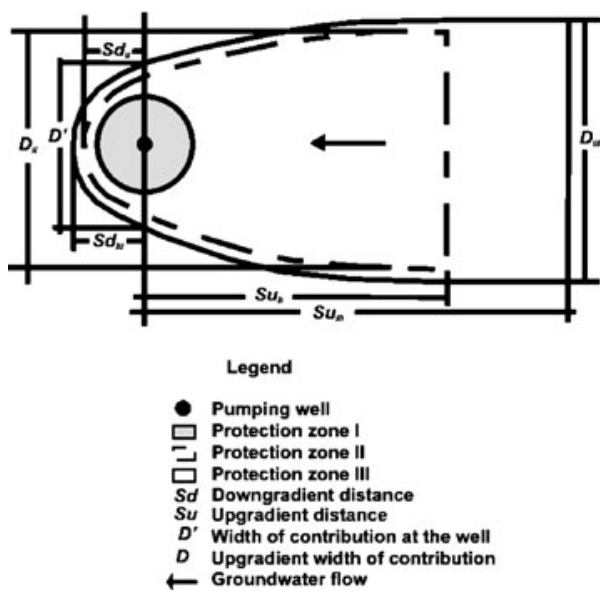

the polluting activities that are carried out within them (Fig. 2). The zones are the following (US Environmental Protection Agency 1993, 1994; Moreno and Martínez 1991; Martínez and García 2003):

- Immediate zone or absolute restriction zone (zone I). This zone is the closest to the well. Its primordial goal is to protect it and its installations against inclement weather and animal action; likewise, it prevents the direct infiltration into the well. The delineation criterion tends to be of a time of travel (time necessary for a pollutant to enter the well) of $24 \mathrm{~h}$ or a small area established in an arbitrary fashion.

- Proximate zone or maximum restriction zone (zone II). It represents the perimeter's main body. It includes an area that is variable but enough to protect water against microbiological pollution, either by ensuring the inactivation, elimination or dilution of the pollutant, or by allowing an alert with enough time to take the necessary measures before the foreign substance reaches the well.

- Remote zone or moderate restriction zone (zone III). This zone must protect the well against persistent pollutants, basically non-degradable or hardly degradable chemical contamination (heavy metals, hydrocarbons and organic compounds). The protection philosophy in this area is based, therefore, on dilution or alert processes, in addition to degradation or inactivation.

A brief description of methods so elected is as follows:

Calculated fixed radius method: volume version

The first of the versions corresponds to the calculated fixed radius method, which was chosen for being one of the methods that adapted to the study area due to its simplicity and low cost. Nevertheless, even though the use of this method increases precision in regards to the use of the arbitrary fixed radius, it continues to be a method that provides little accuracy, since it considers a very limited number of factors. However, when there are limitations in time, funding, or personnel, this 
method is an appropriate starting point (Miller et al. 2003). The radius of protection perimeter $(R)$ is defined as:

$$
R=\sqrt{\frac{Q(t)}{n \pi b}}
$$

were, $Q$ is the pumped volume, $t$ is the time of travel, $n$ is the effective porosity and $b$ is the saturated thickness in the well. The value of $R$ is the upgradient distance $(\mathrm{Su})$ and the downgradient distance $(S d)$.

Analytical method: Wyssling version

The method is based on the calculation of the zone of contribution of a given time of travel. This method is a simple procedure applicable in homogeneous aquifers, which requires a previous pumping test. The perimeter protection for a specific time of travel is calculated from the distance from the pumping well to the downgradient boundary of the zone of contribution $(A)$, the width of contribution at the pumping well $\left(D^{\prime}\right)$, the upgradient distance $(S u)$, the downgradient distance $(S d)$ and the upgradient width of contribution due to the pumping rate $(D)$. These parameters are calculated as follows (Wyssling 1977 in Moreno and Martínez 1991):

$$
\begin{gathered}
A=\frac{Q}{2 \pi K b i} \\
D^{\prime}=\frac{Q}{2 K b i} \\
S u=\frac{+d+\sqrt{d(d+8 A)}}{2} \\
S d=\frac{-d+\sqrt{d(d+8 A)}}{2} \\
D=\frac{Q}{K b i}
\end{gathered}
$$

were $K$ is the hydraulic conductivity, $i$ the natural hydraulic gradient and $d=v^{*} t$, where $t$ is the desired time of travel and $v$ is the velocity of groundwater flow without pumping interference $(Q=0)$. The other parameters match the previous method.

The Wyssling version was chosen for being one of the well-knowing and used methods for the delineation of protection areas.

Analytical method: Minkin version

This method has been used for confined aquifers but also for unconfined aquifers on the condition that the decline of groundwater level by pumping was small relative to the aquifer thickness (Oradoskaia and Lapchin 1987). The values of the parameters to define the WHAPA is obtained by estimating the downgradient boundary of zone of contribution of the well $\left(X_{P}\right)$, the indirect parameter of calculation $\left(t^{*}\right)$, 
the upgradient distance $(S u)$, the downgradient distance $(S d)$ and the width of the perimeter (D).

$$
\begin{gathered}
X_{p}=\frac{Q}{2 \pi K b i} \\
t^{*}=\frac{K i t}{n X_{p}} \\
S u=R X_{p} \\
S d=r X_{p} \\
D=2 d X_{p}
\end{gathered}
$$

were $n$ is the effective porosity. The other parameters match the previous methods. Having defined the value $\mathrm{t}^{*}$, we derive the parameters $R^{*}, r^{*}$ and $d^{*}$ from the values established by Oradoskaia and Lapchin (1987).

The Minkin version has been widely used in different countries in Europe (Exposito et al. 2007).

Analytical method: Pérez and Menéndez version

Perez et al. (1998), introduced another option for calculating of WHPA. The equations used are:

$$
\begin{gathered}
S d=\frac{Q}{2 \pi K b i} \\
D=\frac{Q}{K b i} \\
S u=\sqrt{\frac{Q}{\pi b n} t+r_{p}}+\frac{K i}{n} t
\end{gathered}
$$

were $r_{p}$ is the well radius. The other parameters match the previous methods.

The Perez-Menendez version has been used in Cuba as a basis for said country's regulation in regards to well protection.

Once assessment of the dimensions of the WHPAs has been conducted based on the different methods mentioned previously, a comparison among them was conducted, applying the areas of coincidence criterion (Paradis et al. 2007) which is recommended when comparing methods of the same hierarchy (in this case, among analytical methods). This criterion consists of superimposing the results of the obtained WHPAs with the different methods and choosing the method that defines a perimeter that comprises the area that is delineated when superimposing all the WHPAs and in which all methods concur. 


\section{Results and Discussion}

\subsection{Vulnerability Map}

Once the method to be used is defined, in this case GOD, an evaluation of the parameters was conducted:

\section{(a) Determination of the degree of hydraulic confinement or aquifer type $(G)$}

The geological map prepared by UNAM (1994) was used as a basis for the analysis. The degree of the aquifer's hydraulic confinement was identified and a value was assigned to this parameter in a scale from 0.0 to 0.8 (Fig. 3a)

(b) Determination of the characteristics of the overlying strata or vadose zone lithology $(\mathrm{O})$

Characteristics of the strata overlying the saturated zone were specified based on the type of lithology (indirectly considering effective porosity and infiltration coefficient), and a value was assigned to this parameter in a scale from 0.5 to 0.9 (Fig. 3b).
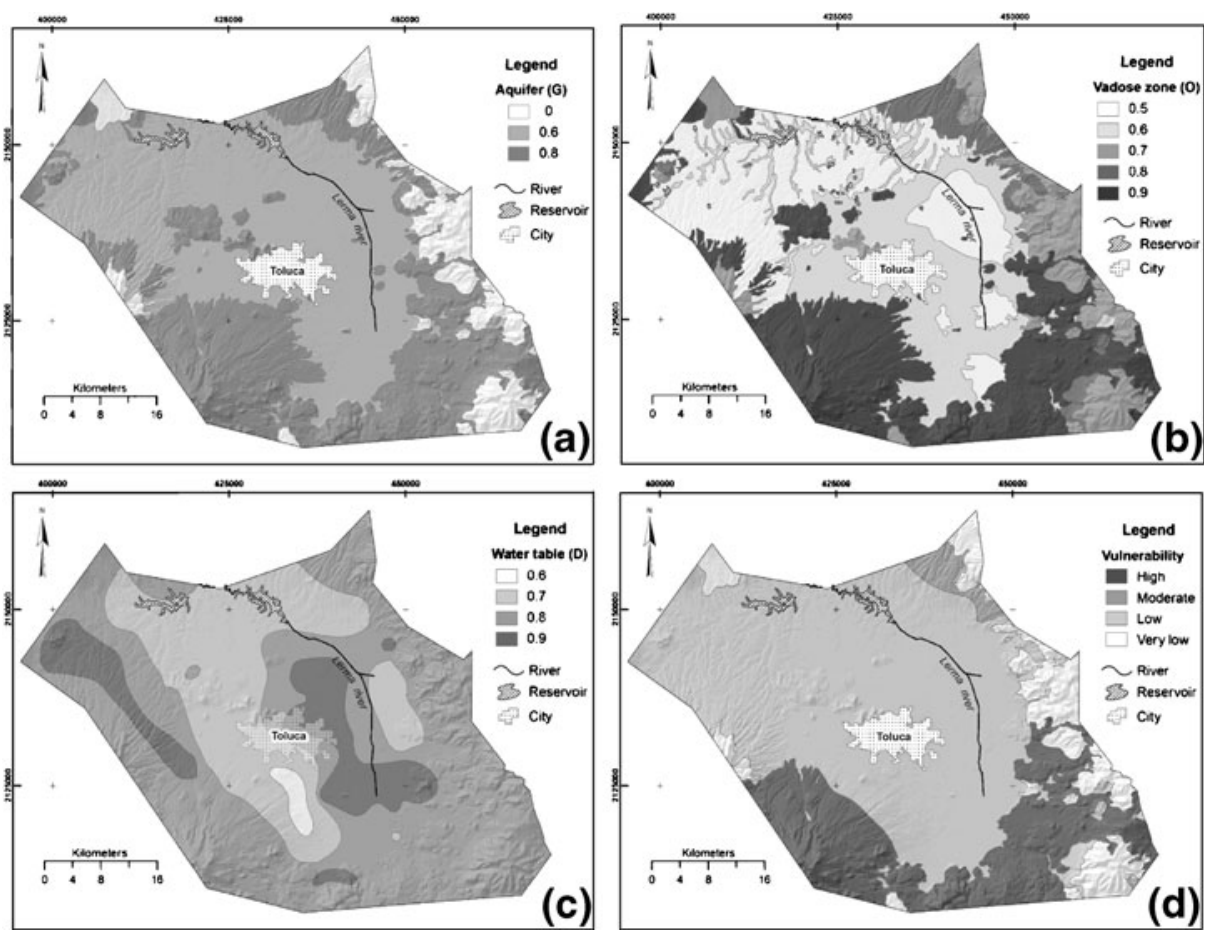

Fig. 3 a Groundwater occurrence map. b Overlying lithology characteristics map. c Variability of the depth to the water table map. d GOD map for the study area 


\section{(c) Depth to groundwater (D)}

Based on interpolations conducted with the water table level data, depth to groundwater was estimated, with the assignation of different values in a scale from 0.6 to 0.9 (Fig. 3c). To determine the depth of groundwater level, data can be used which are obtained in the piezometric monitoring networks of the aquifer. This network is made up of 56 piezometers operated by CONAGUA.

The GOD pollution vulnerability map was conducted through a series of polygon overlaps using ArcView software. The resulting map is shown in Fig. 3d. It is possible to see that the most vulnerable areas are located in the recharge zones, which correspond to the mountainous areas where fractured volcanic materials appear, whereas in the valley the degree of vulnerability is low.

\subsection{Selection and Prioritization of Supply Wells}

Once the areas of highest vulnerability were delineated, public water wells located within those areas were identified. With the data of the identified wells, which are 49 in total (Fig. 4), a database was elaborated indicating for each well the annual pumped volume, which fluctuated between 3.9 and $0.01 \mathrm{Mm}^{3} /$ year, and the year in which it was constructed. Also specified in the database was land use in the area surrounding the well, showing the predominance of agricultural use and the low variability of this attribute, which is why this criterion was not included in the final analysis.

The index of social inclusion of the population located near wells was also consulted. Once this index was consulted, special attention was paid to populations with a high value of this index, considering that these populations are the ones that

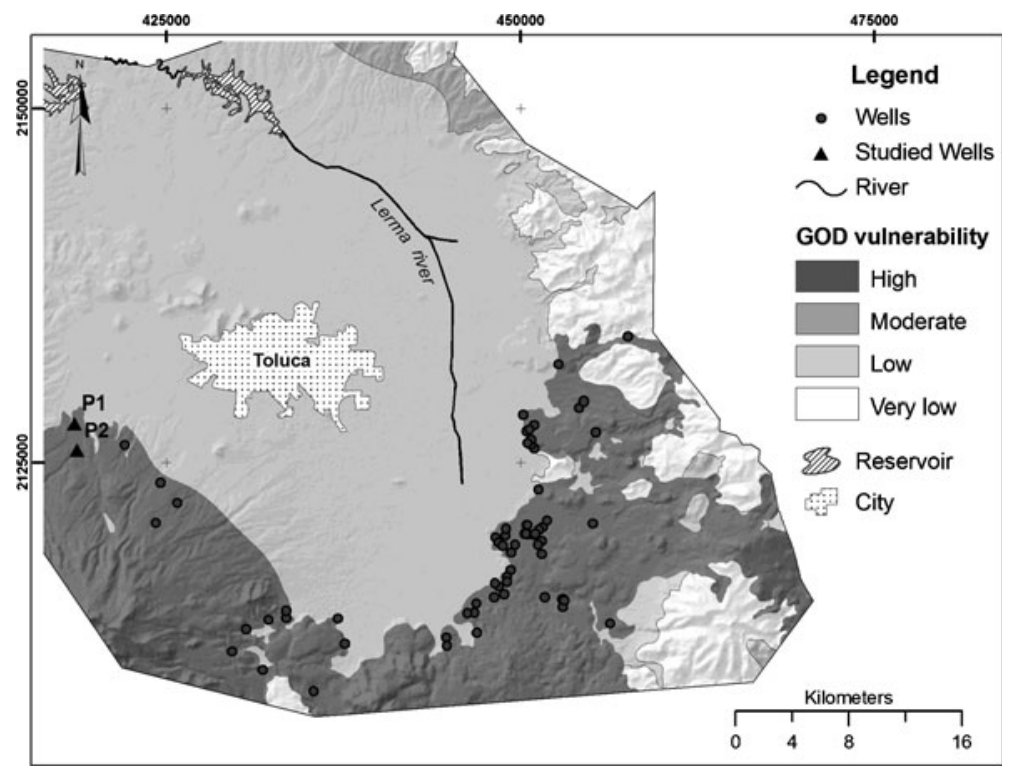

Fig. 4 GOD vulnerability map and public drinking wells location 
have the lowest percentage of sewerage coverage and therefore could be a focus of contamination.

The social exclusion index in the prioritization of wells was not only considered as a way of evaluating the potential contaminant load that could reach the aquifer, but it also useful in the evaluation of material and human resources that are available for maintaining the well in proper exploitation conditions, for locating alternative sources of water supply in the case of contamination events, or even to have proper medical attention in the face of waterborne diseases.

Once all the information is obtained, wells with highest pumped volumes, the oldest ones, and those located downgradient of populations with high index of social exclusion were identified as the ones that would have priority protection-wise since these are the wells that show the highest risk of contamination.

\subsection{WHPA Methods Application and Comparison}

Once the priority wells were identified, two of them were chosen (San Isidro WellP1 and Santa Juanita Well-P2) to conduct a pilot study (Fig. 4). The different chosen methods were applied to these wells.

For the definition of zone I of the protection area, it was considered that, since this zone is generally defined in an arbitrary fashion, then its determination would not be necessary and in the study cases, it corresponded to the fenced area surrounding the well.

The calculations were directed towards establishing the dimensions of zones II and III of the perimeter, assessing the following parameters: $S u$ and $S d$ are the upgradient and downgradient distance, respectively, from the pumping well to a point on the flow axis with the desired time of travel, $D$ is the upgradient width of contribution in meters due to the pumping rate and $D^{\prime}$ is the width of contribution at the pumping well in meters (Fig. 2); for this, the input values shown in Table 1 were used.

Table 1 Hydrogeological parameters used with WHPA delineation methods

\begin{tabular}{|c|c|c|c|c|c|}
\hline Well & Parameters & Symbol & & Values & Source of information \\
\hline \multirow[t]{7}{*}{$\overline{\text { San Isidro P1 }}$} & Pumped volume & $Q$ & $\mathrm{~m}^{3} /$ day & 3,110 & Survey \\
\hline & Saturated thickness & $b$ & M & 210 & Survey \\
\hline & Effective porosity & $n$ & Adimensional & 0.18 & Custodio and Llamas (1983) \\
\hline & Hydraulic gradient & $i$ & Adimensional & 0.034 & Survey \\
\hline & Hydraulic conductivity & $K$ & $\mathrm{~m} /$ day & 1.7 & Survey \\
\hline & $\begin{array}{l}\text { Time of travel } \\
\text { (zone II) }\end{array}$ & $t$ & Days & 60 & Moreno and Martínez (1991); \\
\hline & $\begin{array}{l}\text { Time of travel } \\
\text { (zone III) }\end{array}$ & $t$ & Days & 3,650 & Martínez and García (2003) \\
\hline Santa & Pumped volume & $Q$ & $\mathrm{~m}^{3} /$ day & 3,024 & Survey \\
\hline \multirow[t]{6}{*}{ Juanita P2 } & Saturated thickness & $b$ & $\mathrm{~m}$ & 200 & Survey \\
\hline & Effective porosity & $n$ & Adimensional & 0.18 & Custodio and Llamas (1983) \\
\hline & Hydraulic gradient & $i$ & Adimensional & 0.034 & Survey \\
\hline & Hydraulic conductivity & $K$ & $\mathrm{~m} /$ day & 1.7 & Survey \\
\hline & $\begin{array}{l}\text { Time of travel } \\
\text { (zone II) }\end{array}$ & $t$ & Days & 60 & Moreno and Martínez (1991); \\
\hline & $\begin{array}{l}\text { Time of travel } \\
\text { (zone III) }\end{array}$ & $t$ & Days & 3,650 & Martínez and García (2003) \\
\hline
\end{tabular}


The times of travel (time necessary for water or contaminant to reach the well from the location) that were chosen were 60 days in zone II (maximum restriction) and 3,650 days in zone III (moderate restriction), these times being considered enough to protect the well from bacteriological contamination in zone II and from persistent contamination in zone III (Moreno and Martínez 1991; Martínez and García 2003).

It must be taken into account that any uncertainty in the data reliability means that the well is not being completely protected; therefore, it is a common practice to multiply the results obtained by factors of safety or to insert such factors into the formulas of the calculations (NC 93-01-209 1990; WDEQ 2003; Exposito et al. 2007). In the analyzed case, the results were multiplied by 1.3 , so that, once the factor of security is applied, the results obtained with the original formulas define WHPAs of larger dimensions.

The dimensions obtained of the WHPAs are shown in Table 2, once the factor of security was applied. It is necessary to emphasize that the differences that were obtained for the different protection areas of each well in the study, when using the same method, were minimal. This is because the only parameter that is different in the input data is pumped volume, whereas the hydrogeological characteristics of the areas in which the wells are located, based on data obtained from the geological map as well as from the well's stratigraphic column, indicate that the wells are built in the same geological environment.

The results obtained with the use of the different methods for the delineation of WHPAs for both the San Isidro Well-P1 and the Santa Juanita Well-P2 show significant variability (Table 2 and Fig. 5a, b), which is especially marked in zone III (Fig. 5b). For example, in the case of the Santa Juanita Well-P2, the downgradient distance that was obtained for zone III is $405 \mathrm{~m}$. with the calculated fixed radius, which is four times the distance obtained with Wyssling's method of $102 \mathrm{~m}$. On the other hand, the upgradient dimensions determined with the fixed radius method are smaller than those obtained with the analytical methods. This means that the

Table 2 Calculated parameters with WHPA delineation methods

\begin{tabular}{|c|c|c|c|c|c|c|}
\hline \multirow[t]{2}{*}{ Method } & \multicolumn{3}{|l|}{ Zone II } & \multicolumn{3}{|l|}{ Zone III } \\
\hline & $\begin{array}{l}\text { Upgradient } \\
S u(\mathrm{~m})\end{array}$ & $\begin{array}{l}\text { Downgradient } \\
S d(\mathrm{~m})\end{array}$ & $\begin{array}{l}\text { Width } \\
D(\mathrm{~m})\end{array}$ & $\begin{array}{l}\text { Upgradient } \\
S u(\mathrm{~m})\end{array}$ & $\begin{array}{l}\text { Downgradient } \\
S p(\mathrm{~m})\end{array}$ & $\begin{array}{l}\text { Width } \\
D(\mathrm{~m})\end{array}$ \\
\hline \multicolumn{7}{|l|}{ San Isidro-P1 } \\
\hline $\begin{array}{l}\text { Calculated fixed } \\
\text { radius }\end{array}$ & 51 & 51 & 102 & 402 & 402 & 804 \\
\hline Wyssling & 65 & 40 & $\begin{array}{l}D^{\prime}=166 \\
D=333\end{array}$ & 1,617 & 98 & $\begin{array}{l}D^{\prime}=166 \\
D=333\end{array}$ \\
\hline Perez-Menendez & 76 & 53 & 333 & 1,924 & 53 & 333 \\
\hline Minking & 70 & 36 & 101 & 1,706 & 53 & 319 \\
\hline \multicolumn{7}{|l|}{ Santa Juanita-P2 } \\
\hline $\begin{array}{l}\text { Calculated fixed } \\
\text { radius }\end{array}$ & 52 & 52 & 104 & 405 & 405 & 810 \\
\hline Wyssling & 66 & 41 & $\begin{array}{l}D^{\prime}=170 \\
D=340\end{array}$ & 1,620 & 102 & $\begin{array}{l}D^{\prime}=170 \\
D=340\end{array}$ \\
\hline Perez-Menendez & 77 & 54 & 340 & 1,928 & 54 & 340 \\
\hline Minking & 71 & 37 & 102 & 1,715 & 54 & 326 \\
\hline
\end{tabular}




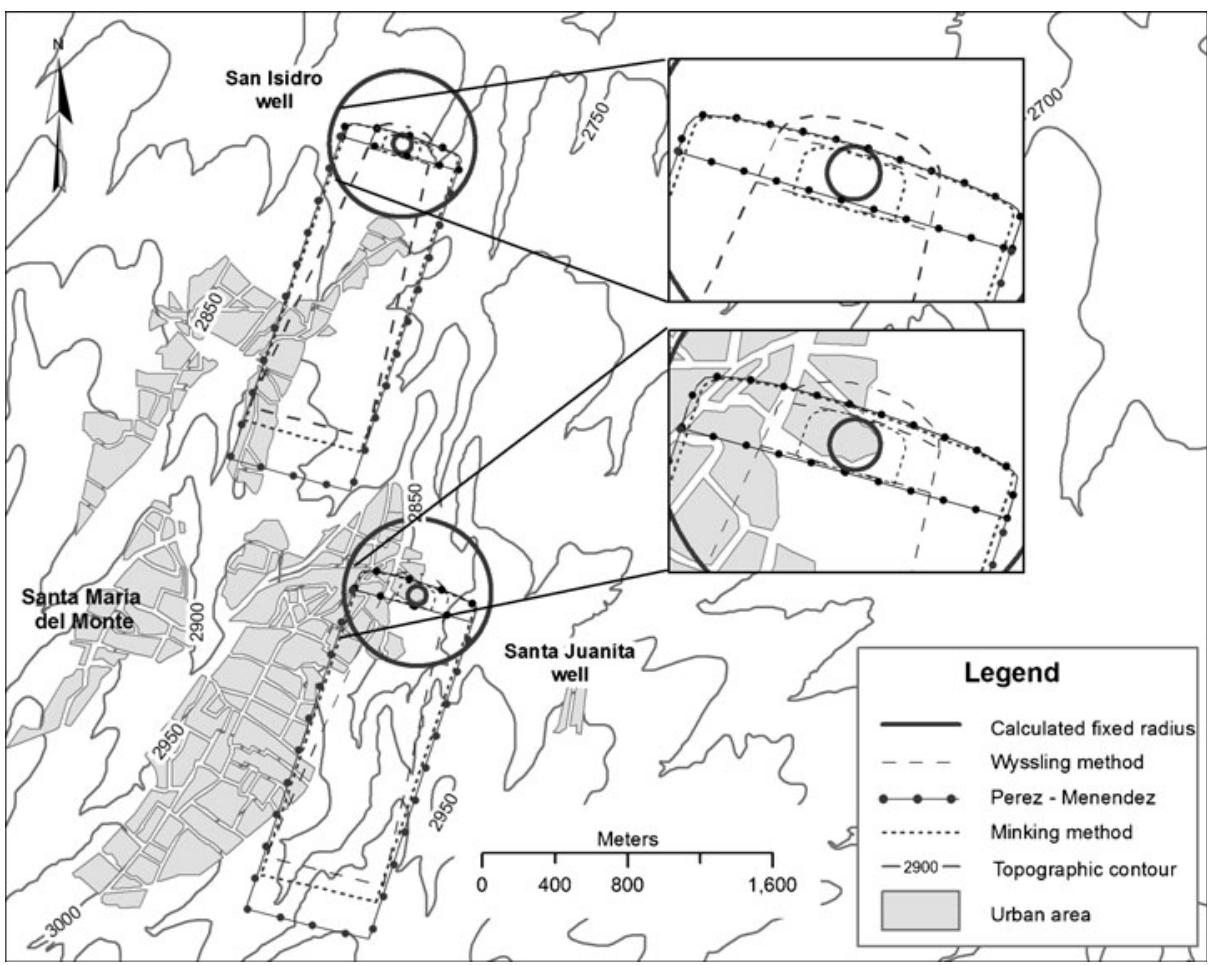

Fig. 5 Comparison of the WHPAs at the San Isidro P1 and Santa Juanita P2 wells

calculated fixed radius method overprotects the well's downgradient area and does not protect correctly the well's upgradient. This is because it does not consider the aquifer hydraulic gradient in its calculations.

On the other hand, when comparing the results obtained for both wells with the analytical methods, it is observed that the most apparent differences occur because the Wyssling method considers a smaller perimeter width at the height of the well than the other methods, a situation which could put the well at risk due to the uncertainty that could exist in the assessment data.

Considering these elements, it is concluded that the most adequate method to be used in the area is the Minkin method, since it properly protects the well at its sides and achieves a balance in the upgradient distances, positioning itself between the value obtained by the Wyssling method and that obtained by the Perez-Menendez method. In addition, making a comparison with the areas of coincidence criterion, it is possible to show that the WHPA defined with the Minkin method has a coincidence with the rest of the calculated WHPAs of $98.96 \%$ for the case of the San Isidro Well-P1 and 99.07\% for the case of the Santa Juanita Well-P2.

The previously mentioned elements are common for both wells given the similarities of the area's hydrogeological characteristics and of their respective constructions.

Once the protection areas of each well were delineated, we proceeded with the identification of the sources of contamination by going through the field (Table 3). The potential sources of contamination that were possible to identify and 
Table 3 Summary of activities potentially generating a contaminant load

\begin{tabular}{llllll}
\hline Pollution focus & \multicolumn{2}{c}{ San Isidro-P1 } & & \multicolumn{2}{c}{ Santa Juanita-P2 } \\
\cline { 2 - 3 } \cline { 6 - 7 } & Zone II & Zone III & & Zone II & Zone III \\
\hline Animal waste storage & - & 2 focus & & 1 focus & - \\
Sewage discharge & - & 2 focus & & 2 focus & 3 focus \\
Septic tank & - & 3 focus & & - & 3 focus \\
Landfill & - & 1 focus & - & 3 focus \\
Agricultural & - & $0.42 \mathrm{~km}^{2}$ & - & $0.72 \mathrm{~km}^{2}$ \\
fertilizer use & & & & & \\
\hline
\end{tabular}

were located within the WHPA, in the case of the San Isidro Well-P1, were several, including urban and agricultural sources of contamination. In the zone II (60 days) of the area, no contamination source was identified, whereas in the zone III, several sources of contamination were detected, among them the population's sewer system, since the perimeter's dimensions included $60 \%$ of the urban stain, and other sources of contamination such as latrines, uncontrolled municipal solid waste landfills, and agricultural-cattle activities (Fig. 6).

Unlike the San Isidro Well-P1, where sources of contamination were only found in Zone III, in the case of the Santa Juanita Well-P2 (Fig. 6), several types of contaminating activities were detected in both zones II and III. The registered

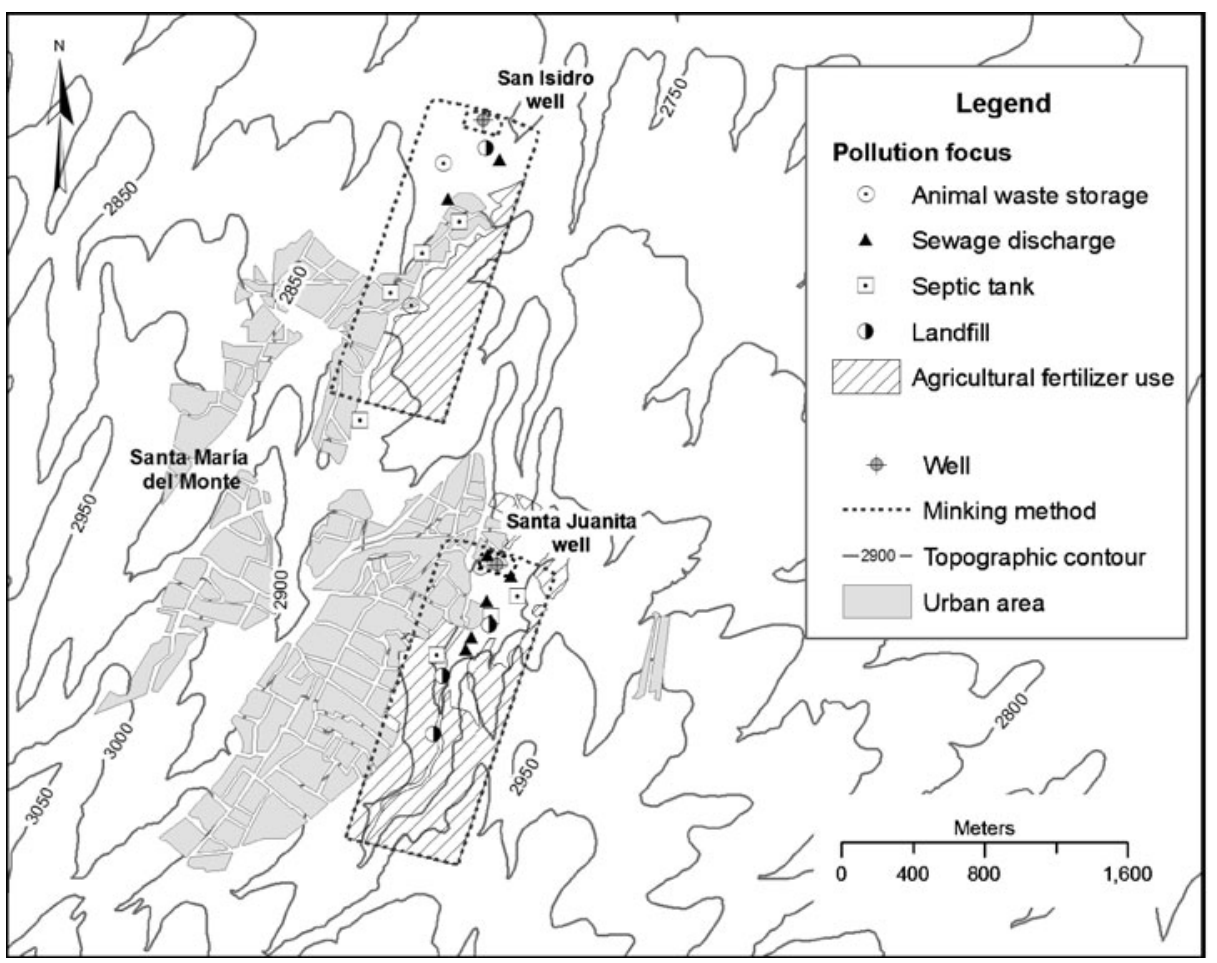

Fig. 6 Pollution sources in the WHPA at de San Isidro P1 and Santa Juanita P2 wells 
sources of contamination were wastewater discharge directly into the soil, latrines, uncontrolled municipal solid waste landfills and rivers with wastewater discharge.

In the face of this situation, the appropriate authorities should propose a series of guidelines within the framework of land-use planning, that stress the restriction or cancellation of contaminating activities within the territorial sphere of the defined WHPAs or remove the wells, especially in the case of the Santa Juanita Well-P2 where sources of contamination were identified inside zone II (maximum restriction zone).

\section{Conclusions}

The aquifer vulnerability map shows that the areas of highest vulnerability are located in the aquifer's main recharge areas. This situation shows the need to protect the wells that are located within these areas.

The criteria used to prioritize the public water wells located in this highest vulnerability areas were mainly focused on the wells' constructive characteristics and on the existence of populations with high value of index of social exclusion. The land use criterion did not have much influence since it exhibited scarce variability.

Wells with highest pumped volumes, the oldest ones, and those located downgradient of populations with high index of social exclusion were identified as the ones that would have priority protection-wise since these are the wells that show the highest risk of contamination.

Making a comparison the results obtained with the use of the different methods for the delineation of WHPAs (calculated fixed radius method and the analytical methods in the versions of Wyssling, Minkin, and Perez and Menendez), it is concluded that the most adequate method to be used in the study area is the Minkin method. On the other hand, contaminating activities within the WHPAs were also identified, and so, concrete measures can be taken to either restrict or prohibit these activities or remove the wells. Likewise, pinpointing the sources of contamination that exist within the WHPAs, allows defining which physical, chemical and/or biological parameters must be monitored in the well water in order to easily detect their effect on the water quality.

The dimensions of the perimeters obtained in this work can be used to define the perimeters of wells that have already been constructed or that are to be constructed within the study area.

Acknowledgements The authors wish to express their gratitude to the Universidad Autonoma del Estado de México (Project 1938/2004-2) for providing financial support. Particular thanks are given to Comision Nacional del Agua (CONAGUA) for their helpful technical support.

\section{References}

Aller L, Bennet T, Leher JH, Petty RJ (1985) DRASTIC: a standardized system for evaluating groundwater pollution potential using hydrogeologic settings. US EPA Report 600/2-87-035. US Environmental Protection Agency, Washington, DC

Auge M (2003) Vulnerabilidad de acuíferos, conceptos y métodos. Rev. Latinoamericana de Hidrogeología 3:93-98 
CCRECRL Comisión Coordinadora para la Recuperación Ecológica de la Cuenca del Río Lerma (1993) Atlas Ecológico de la Cuenca Hidrográfica del río Lerma. Gobierno del Estado de México. México

Civita M (1994) La carte della vulnerability degli acquiferi all'inquinamento. Teoria \& Practica. Pitagora, Bologna

CONAGUA Comisión Nacional del Agua (2002) Determinación de la disponibilidad de agua en el acuífero del Valle de Toluca, Estado de México CONAGUA Gerencia de Aguas Subterráneas, México DF

CONAPO Consejo Nacional de la Población (2001) Índices de marginación: regional, municipal y por localidad. Gobierno Federal, México DF

Custodio E, Llamas JR (1983) Hidrologia Subterranea, 2nd edition Editorial Omega, Barcelona

De Loë RC, Di Giantomasso SI, Kreutzwiser RD (2002) Local capacity for groundwater protection in Ontario. Environ Manag 29:217-233

Esteller MV, Andreu JM (2005) Antropic effects on hydrochemical characteristics of the Valle de Toluca aquifer (Central Mexico). Hydrogeol J 13:378-390

Esteller MV, Díaz-Delgado C (2002) Environmental effects of aquifer overexploitation: a case study in the Highlands of Mexico. Environ Manag 29(2):266-278

Exposito JL, Garfias J, Franco R, Esteller MV (2007) Delineation of the wellhead protection area in an unconfined aquifer with variable vertical hydraulic conductivity. Ing Hidraul Mex XXII(2):55-68

Fadlelmawla AA, Dawoud MA (2006) An approach for delineating drinking water wellhead protection areas at the Nile Delta, Egypt. J Environ Manage 79(2):140-149

Foster S, Hirata R (1988) Groundwater pollution risk assessment: a methodology using available data. WHO-PAHO/HPE-CEPIS Technical Manual, Lima, 81 pp

Foster S, Hirata R, Gomes D, D'Elia M, Paris M (2002) Groundwater quality protection: a guide for water utilities in Municipal Authorities and Environmental Agencies. World Bank Publication Washington, DC, $115 \mathrm{pp}$

Frind EO, Molson JW, Rudolph DL (2006) Well vulnerability: a quantitative approach for source water protection. Ground Water 44(5):732-742

Garfias J, Exposito JL, Llanos H (2008) Delimitación de las zonas de protección mediante metodos analiticos y un modelo numérico de agua subterránea, acuifero Margarita, Cuba. Boletín Geologico y Minero 119(1):7-19

Gogu RC, Dessargues A (2000) Current trends and future challenges in groundwater vulnerability assessment using overlay and index methods. Environ Geol 39:549-559

Gogu RC, Hallet V, Dessargues A (2003) Comparison of aquifer vulnerability assessment techniques. Application to the Nébol river basin (Belgium). Environ Geol 44:881-892

Hirata R, Reboucas A (1999) La protección de los recursos hídricos subterráneos: Una visión integrada basada en perímetros de protección de pozos y vulnerabilidad de acuíferos. Boletín Geológico y Minero 4:423-436

INEGI Instituto Nacional de Estadística y Geografia (2003) Mapa de Usos del Suelo. Instituto Nacional de Estadística y Geografia México, DF

Martínez C, García A (2003) Perímetros de protección para captaciones de agua subterránea destinadas al consumo humano. Metodología y aplicación al territorio, Boletín Geológico y Minero, Serie Hidrogeología y Aguas Subterráneas No. 10, 273 pp

Massone H, Londoño MQ, Martínez D (2010) Enhanced groundwater vulnerability assessment in geological homogeneous areas: a case study from the Argentine Pampas. Hydrogeol J 18: 371-379

Miller C, Chudek P, Bedcock S (2003) A comparison of wellhead protection area delineation methods for public drinking water systems in Whatcom County Washington. J Environ Health 66(2):17-24

Montgomery MA, Elimelech M (2007) Water and sanitation in developing countries: including health in the equation. Environ Sci Technol 41(1):17-24

Moreno L, Martínez C (1991) Guía metodológica para la elaboración de perímetros de protección de captaciones de aguas subterráneas. Instituto Tecnológico Geominero de España. (ITGE), $290 \mathrm{pp}$

NC 93-01-209 (1990) Norma Cubana. "Procedimiento de cálculo para la determinación de la zona de protección sanitaria". Instituto de Normalización de la República de Cuba, 43 pp

Nel J, Xu Y, Batelaan O, Brendonck L (2009) Benefit and implementation of groundwater protection zoning in South Africa. Water Resour Manag 23:2895-2911. doi:10.1007/s11269-009-9415-4 
Neukum C, Hötzl H, Himmelsbach T (2008) Validation of vulnerability mapping methods by flied investigations and numerical modeling. Hydrogeol J 16(4):641-658

Oradoskaia AM, Lapchin NN (1987) Sanitary protection of groundwater wells. Nedra, Moscú, 168 pp (in Russian)

Paradis D, Martel R, Karanta G, Lefebvre R, Michaud Y, Therrien R, Nastev M (2007) Comparative study of methods for WHAPA delineation. Ground Water 45(2):158-167

Perez F, Menendez A, Perez O (1998) Experiencias en el cálculo de la distancia de protección sanitaria en las fuentes de abasto de aguas subterráneas en las provincias de Ciudad de la Habana y Matanzas. Cuba. Archivos CENHICA-INRH, 13 pp

Sylvestre B, Rodriguez ML (2008) Protection strategies for drinking groundwater sources in small Quebec municipalities. J Environ Manag 88:28-42

UN United Nations (2006) The 2nd United Nations World Water Development Report: 'Water, a shared responsibility'. United Nations World Water Assessment Program (WWAP). United Nations Educational, Scientific and Cultural Organization (UNESCO) Paris, France and Berghahn Books, New York

UNAM Universidad Nacional Autónoma de México (1994) Carta Geológica del Estado de México. Instituto de Geología UNAM

Unitecnia Company (1996) Estudio para el diseño de redes de monitoreo de los acuíferos de los Valles de Toluca y Atlacomulco-Ixtlahuaca, en el Estado de México. Informe técnico. Comisión Nacional del Agua, 66 pp, planos y anexos

US Environmental Protection Agency (USEPA) (1993) Guidelines for delineation of wellhead protection areas. EPA-440/5-93-001. US Environmental Protection Agency, Washington, DC

US Environmental Protection Agency (USEPA) (1994) Groundwater and wellhead protection handbook. EPA-625/R-91-001. US Environmental Protection Agency, Washington, DC

Van Stempvoort D, Ewert L, Wassenaar L (1992) AVI: a method for groundwater protection mapping in the Prairie Provinces of Canada. Regina. Prairie Provinces Water Board, Canada

Vrba J, Zaporec A (1994) Guidebook on mapping groundwater vulnerability. Int Contrib Hydrogeol 16:131

Wang W (2006) Optimal environmental management strategy and implementation for groundwater contamination, prevention and restoration. Environ Manag 37:553-566

WDEQ Water Quality Division (2003) Methods for the delineation of wellhead protection areas (WHPAs). Available via http://www.wrds.uwyo.edu/wrds/deq/whp/whpappd.html, Accessed 10 Aug 2003 